\title{
The Role of Agricultural Engineering to Take Agriculture to Greater Height in Adamawa State
}

\author{
D. A. Mada ${ }^{1}$, I. D. Husseini ${ }^{1}$, G. A. Idris ${ }^{1} \&$ Sunday Mahai ${ }^{2}$ \\ ${ }^{1}$ Department of Agricultural Engineering, Adamawa State College of Agriculture, Ganye, Nigeria \\ ${ }^{2}$ Department of Agricultural Extension and management, Adamawa State College of Agriculture, Ganye, Nigeria \\ Correspondence: D. A. Mada, Department of Agricultural Engineering, Adamawa State College of Agriculture, \\ Ganye, Nigeria. Tel: 234-810-031-4523. E-mail: Madadaniel4@gmail.com
}

\author{
Received: May 6, 2013 Accepted: June 5, 2013 Online Published: August 15, 2013 \\ doi:10.5539/jas.v5n9p51 URL: http://dx.doi.org/10.5539/jas.v5n9p51
}

\begin{abstract}
Food is the first step to every development in a nation. The economic growth of any state can be more easily fostered through sustaining sufficient food production. The dwarf status of National Agriculture Engineering continued to retrogress like abandon baby. It is yet to meet the reality of 20th century of scientific breakthrough in food production. Thus, the impact of agricultural engineers have been neglected to take agriculture to higher height in national development especially in Adamawa State as a study zone.Agricultural Engineering should be motivated to developed multipurposeand low powered machine to improve agricultural practices and management.
\end{abstract}

Keywords: engineer, machine, agriculture, production

\section{Introduction}

The state is quietly blessed with abundant resources that will aid it to uplift technology and cottage industries. It will sufficiently sustain food production and economic growth. Experience has shown that the level of economic development of any nation depends on its level of human resources; particular science and technology. Bill stout, a senior expert chang ping, state that "Adequate food supplies and a balance diet for everyone will require a significant contribution from Agricultural Engineer around the world".

Agricultural Engineers deal with the of technique, systems and machines for production of goods and services. To improve agricultural practices, the use of machinery and farm power must be combined with soil conservation and management to minimize erosion. However, Agricultural engineering has application of physical knowledge with judgment, in the utilization of materials and forces of nature to improve to improve production practices and management.

The utilization of local resources will solemnly enable us to achieve speedy development and food sufficiency. Whereby, higher and middle level manpower will be gain fully employed.

Agricultural Engineering is manipulation of farm power (tractors) and farm machinery for production of crop and animals. Engineers are directly or indirectly involved in influencing human resources in making decision to take agriculture to higher height.

Engineer designs, fabricates, and installs agricultural machines, construction of farm structures, processing and storage of product. Food production is accelerated in Great Britain, Saudi Arabia, France, Thailand etc. with join effort of farmers and agricultural engineers.

\section{Method}

The main source of methodology used in the study zone as information is Agricultural Engineering in third world countries by May (1985). Engineering for tomorrow Agriculture using experimental methods is a challenge to present situation and contemporary engineers. Hoffen (1960) stated that farmers in developing countries have been using hand tools for thousand years draught animal for centuries and mechanical powered machines for decades. Farm implement were designed 50 years ago does not fit our modern farming system.

Thus, agricultural engineers in contemporary time should be challenged with aid of state government to increase food production; using the following experimental methods. 


\subsection{Servicing and Developing Agricultural Machinery and Equipment}

Field survey in study zone had developed low powered machines for shelling maize, groundnut and cowpea. These machines have transferred fatigue and labor from farmers and grossly improved post harvest operation from 2007 to 2012. The aim of servicing farm machinery is to prolong its estimated useful life. Old fashion tools, implement and machine should be redeveloped to fit the current trend in food production. If machine continues to work it tears and wears unequipped for training future engineers and production of goods and services.

\subsection{Sustainable Source of Water for Irrigation}

The method of sustainable source of water was developed through earth dams had partially met the following requirement in the study zone:

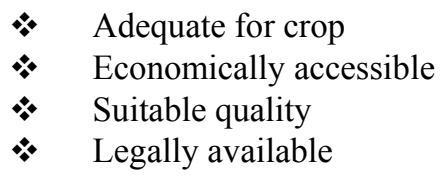

Water is a foundational requirement for both plant and animal. For instance, Saudi Arabia in 1975 with help of oil boom had developed deep-well irrigation technology. Agricultural lands increased from 150, 000 to 26 million hectares of productive land in 1987.

Despite acidity, salinity, infertility condition and labor difficulties in the kingdom. They are now boasting of food sufficient such as wheat, milk, production of poultry and fish farming etc.

Adamawa State with adequate source of irrigation water but failed to execute viable and sustainable irrigation project.

Even "Chouchi Irrigation Project" was abandoned for eight years. Weekly scope $10^{\text {th }}$ June, 2007 reported that the project was awarded in 1999 up till date is not functioning. If this project is completed, it will create job opportunity for agricultural engineers, raw material for cottage industries. Other field report by Chinsuwa and Chochran (1986) highlight effective methods to long time water problem in Saudi Arabia of arid region is solved by effort of civil and agricultural engineers. They also worked massively (1981) on Syria's Euphrates irrigation to achieve international standard. The Euphrates dam will irrigate 640, 000 hectares of land for 30 years.

\subsection{Soil Conservation Technology}

The Engineering innovations to conserved soil in study zone are follows:

* To maintain production of profitable and high yield crops by adopting minimum plough depth as shown in Table 3.2.

* To conserve energy, water, soil and other resources by practicing depth water flowing irrigation over bed

The need of soil conservation and management in developing countries was reported by expert consultant (soil conservation, 1997) that "soil degradation is becoming serious and loss of fertility due to indiscriminate misuse of land, deforestation and overgrazing in study zone on productive lands.

The reality of this condition had exacted worst on part of Adamawa state. The output per hectares is drastically reduced with high input. Hence, agricultural engineers will further address these problems for good utilization of farm lands.

\subsection{Scientific Techniques of Wind Control}

The method of massive deforestation in northern Adamawa, had lead to accelerated desert encroachment on yearly basis. About $85 \%$ of farmers are using corn stalk as fuel for cooking instead wood in 1990's.

Farmers are seriously losing their structures and roofs blown off by violent windstorm. The miss used of powered saw by illegal commercial timber production had caused wind erosion in study zone. For insistence, in 1930, wind blow across the great plain of U.S.A, packing dry top fertile soil and scattering its black dust over Chicago (Wesorster, 1982). Another example of soil degradation in development countries in 1968, a drought set across Sahel in Africa, people struggle to survive for 6 years, but failed as Sahel dust established on productive soil.

The problem is approaching us, as result of massive deforestation by power saw in northern Adamawa state. Centre for science and environment (1982), reported in India; about 25-30\% of productive land under cultivation is adversely affected. Field report (1984), by federal Agricultural organization, that total area of productive lands in Asia, Latin America and Africa will shrink by 544 million hectares over long time owing to erosion. 
Remember, land is farmers bank for transaction of natural resources, the above problems, is important issue for state intervention, Agricultural engineers and environmental protection agency

\subsection{Supply of Crop Processing Machines and Equipment for Small Scale Farmers}

The last methodology in study zone that improved agricultural practices is trough developed model machines. Supply of simple operated low-powered machine such as single-axle combine harvester, corn Sheller, groundnut shelling machine, cowpea thresher garri and starch processing machine and tricycle for handling farm produce. The above simple machines had transformed agricultural production in the state. Youth in the study zone has been encouraged in agricultural activities, since the machines transfer suffering and labor from the farm workers to the machine.

State government has adopted another method of supply low powered machines to small famers to improve agricultural practices. Farm work with tools is tedious and difficult. The use traditional crude processing tools demand a lot of energy from farmers.

In addition it will attract youths to participate in agricultural activities and accelerated food production in the state.

\section{Result}

The result of agricultural innovations in the study zone had improved agricultural practices through manipulation of low-powered multipurpose machine.

Locally developed machines had met the needs of small-scale farmers,' operator's safety and comfort.

Indigenous machine developed in the study zone include: Single axle corn Sheller, cowpea thresher and groundnut shelling had improved quality and quality of agricultural product from 2007-2013.

For sustainable source of water, the flow important of irrigation had been adopted in the study zone. The result of critical velocity $(\mathrm{m} / \mathrm{sec})(\mathrm{C})$ and depth of flowing of water $(\mathrm{M})$ over irrigation bed is shown in Table 1 .

Table 1. Value of critical velocity and depth of water flow in bed

\begin{tabular}{llll}
\hline S/no Experiment & Type of silt grade & Value of C m/sec & Value of M (meters) \\
\hline 1. & Coarse silt & 0.7 & 1.3 \\
2. & Sandy loam silt & 0.65 & 1.2 \\
3. & Coarse high sandy silt & 0.59 & 1.1 \\
4. & High sandy silt & 0.53 & 1.0
\end{tabular}

$\mathrm{C}=$ critical velocity; $\mathrm{M}=$ depth of flow of water over bed.

$\mathrm{M}=\mathrm{V} / \mathrm{v} 0 \mathrm{Vo}=0.55 \mathrm{mDo} .64$, the value varies from 1.1-1.2 for sand and its value decreases from head to tail.

As result of adverse effect of deforestation fertile soil is susceptible to water erosion. However, soil conservation technology had adopted this statistical date of erosivity of fertile soil in the study zone as shown in Table 3.2.

Table 2. Erosivity of fertile soil

\begin{tabular}{lclll}
\hline Time from start & Rainfall $(\mathrm{min})$ & Intensity $(\mathrm{m} / \mathrm{hr})$ & $\begin{array}{l}\text { Kinetic energy } \\
\mathrm{Jm}-2 \mathrm{~mm}-4\end{array}$ & $\begin{array}{l}\text { Total K.E } \\
(\mathrm{col} 2 * \text { col4) } \mathrm{Jm}-2\end{array}$ \\
\hline $0-14$ & & & 8.83 & 13.42 \\
$15-29$ & 1.52 & 6.08 & 27.56 & 391.90 \\
$30-44$ & 14.22 & 50.88 & 28.58 & 747.65 \\
$43-59$ & 26.16 & 104.64 & 28.79 & 906.89 \\
$60-74$ & 31.50 & 126.00 & 26.00 & 217.88 \\
$73-89$ & 8.38 & 33.52 & - & - \\
\hline
\end{tabular}

Source: Akubb C.O. et al. (2006), Fundamental of Engineering for agriculture.

Where, K.E $=13.32+9.28 \log I 10$.

$\mathrm{I}=$ rainfall Intensity in the study zone. 
The level of technology is low in study zone; it will gradually improve to high level with innovations of agricultural engineers. Scarce supply and developed machines had improved production agricultural practices. Modified crop protection machine had improved quality and quantity of crops, vegetables and fruits production.

The result of power requirement for minimum plow of $20 \mathrm{~cm}$ is adopted in the study zone as shown in Table 3.3 .

Table 3. Optimum power requirement for plow $(20 \mathrm{~cm})$ deep

\begin{tabular}{llll}
\hline Types of soil & Unit plough $(\mathrm{KN} / \mathrm{m})$ & Typical speed $(\mathrm{Km} / \mathrm{hr})$ & Unit drawbar power $(\mathrm{KW})$ \\
\hline Clay & 15.3 & 6.44 & 27.38 \\
Loam & 13.9 & 7.30 & 2790 \\
Sandy loam & 10.2 & 8.10 & 11.49 \\
Sandy & 5.1 & 8.10 & 11.49 \\
\hline
\end{tabular}

Source: Akubb C.O. et al. (2006), Fundamental of Engineering for agriculture.

\section{Discussion}

Agricultural engineering had developed low-powered and multipurpose machines in the study zone that removes drudgery in the farm work. A tractor can work for 6 hours without getting tired and related diesel engines and model farm machinery to improve production practices.

We can see from Table 4.1 that availability of engine power for agriculture is low in Nigeria especially in the study zone.

Table 4. Source of power to improve agricultural production

\begin{tabular}{llll}
\hline Source of power & Africa $\%$ & Nigeria \% & USA\% \\
\hline Human power & 89 & 90 & 4 \\
Animal power & 10 & 8 & 1 \\
Engine power & 1 & 2 & 95 \\
\hline
\end{tabular}

Source: Odigboh and Onwuala (1994).

Therefore, relationship between yield and power input in developing countries especially in the study zone is very low in agricultural production as shown in Figure 4.1.

To improve agricultural practices, use of machinery and farm power must be combined with soil conservation and management to minimize erosion as shown in Table 3.1. Field report (1984) by Federal organization that total area of productive lands in Asia, Latin America and Africa will shrink by 544 millions of hectares over long time erosion as shown in Table 3.2. The susceptibility of soil to erosion had caused gross damages to structures and reclamation of fertile lands.

Center for science and environment (1982) reported in India about 25-30\% of productive land under cultivation is adversely affected. Typical example of erosion of fertile soil is shown in Figure 4.2 in Nigeria study location. 


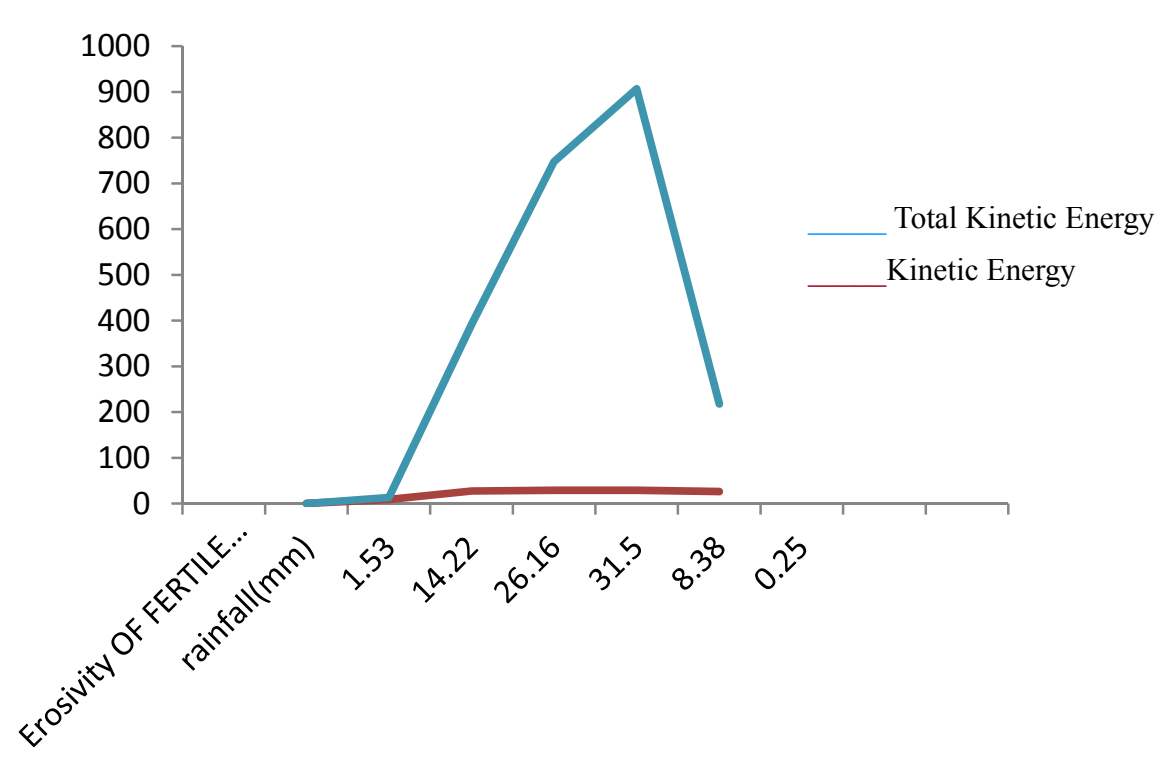

Figure 1. Erosivity of fertile soil under influence of rainfall against kinectic and total kinectic to detached soil

The statistical data presented information, rainfall $(\mathrm{mm})$ falling on deforested land and $\mathrm{K}$. E. require detaching soil particle in study zone.

Rainfall duration is raised gradually which is responsible for surface run of, influenced by land slope.

Statistical information on rainfall duration against total K.E required to remove fertile soil is shown in Figure 4.2 .

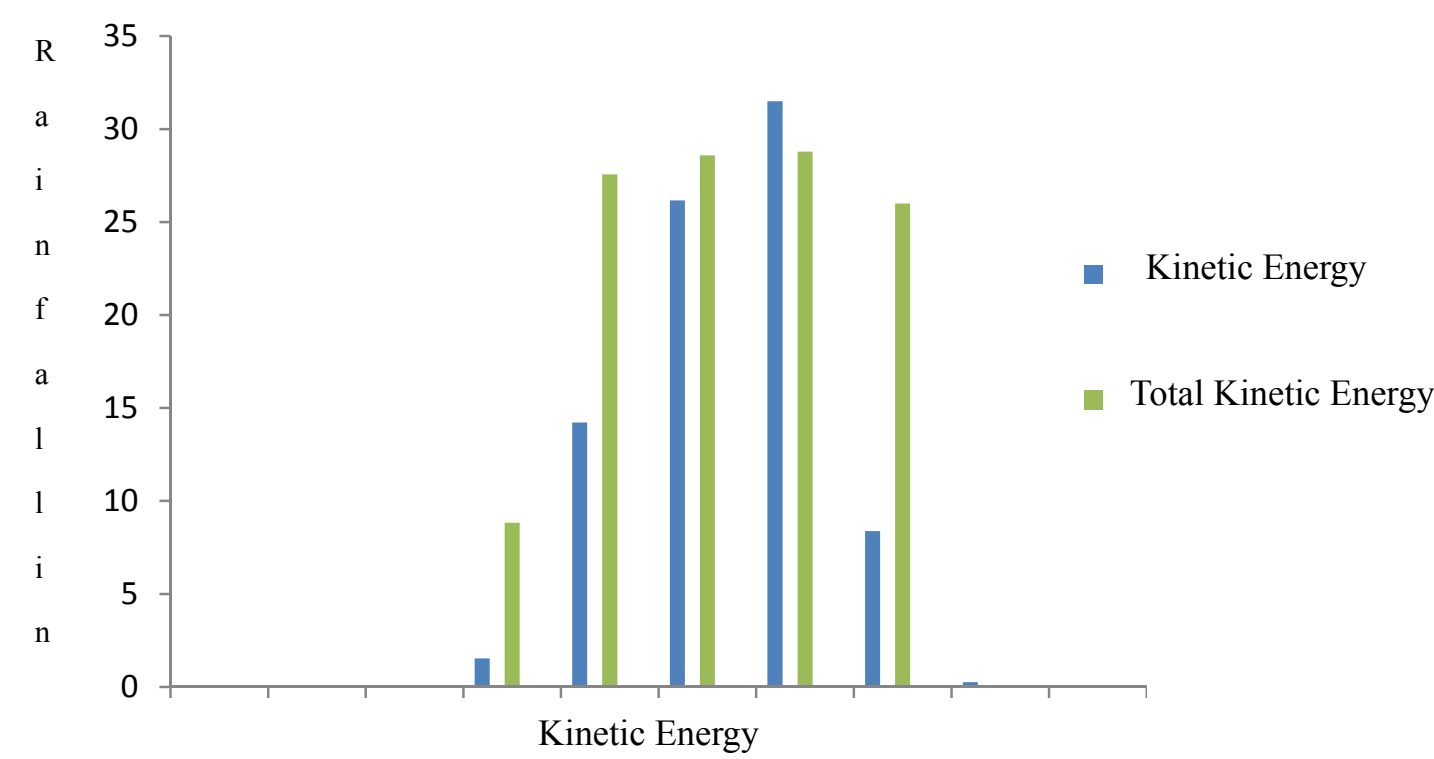

Figure 2. Statistical information on rainfall duration against total kinectic energy to remove fertile soil

As shown in the statically graph, Erosivity is the potential ability of the rain to cause erosion. The relationship between rainfall duration and total K.E. responsible for the scouring action on land surface causing further degradation and removal of fertile soil in study zone.

Another innovation of AG Engineers in the study zone is the greatest step forward in adopted micro-chip and 
rechargeable solar panel. A challenge to African AG engineers in application of solar energy society (S E S) of university of Zimbabwe had developed solar-powered water pump. For small-scale irrigation and animal water supply. The findings are valid and replicable in study Zone. However, the followings recommendations are put forward for government to influence production of goods and services in agriculture.

i. $\quad$ More development of low-powered and multipurpose machines.

ii. Sustainable source of water for irrigation and solar energy powered water pumps.

iii. Fabrication of simple machines and equipment to transfer suffering and intensive labor from small farmers to machines.

iv. Agricultural loan scheme for small-scale farmers to boast production and supplies of low-powered machines.

v. Construction of earth dams in rural area for purpose of irrigation, fishery and animal water supply in the study zone.

\section{References}

Ahmed, I. K. (1984). Farm Equipment Innovation in Eastern, Central and South Africa, Gower publishing Company.

Akubboco, Ahanek I. E., \& Onmuam, A. P. (2006). Fundamental of Engineering for agriculture.

Akubuo, C. O., Ahaneku, I. E., \& Onwualu, A. P. (2006). Fundamentals of Engineering For agriculture, immaculate publication limited-Enugu-Nigeria.

Arku, A. Y. (1999). Role of Agricultural Engineering in solving food production In Nigeria, University of Maiduguri Journal.

Biggs, G., \& Tripathi (2003). Agriculture Mechanization Committee of Bangladesh United nation. Asia and pacific centre for agricultural Agricultural engineering and machinery.

Boumas, G. (1985). Grain handling and storage development in agricultural Engineering, Else Sci. publication Amsterdam.

Kilgour, J. (1979). Engineering for food production in developing Countries.

May, B. A. (1988). British Education and training in international Agricultural development.

Mbamba, N. (2007). Taking Agriculture to greater height, weekly scope Adamawa printing press-Yola-Nigeria.

Mbamba, N. (2008). Taking Agriculture greater height. Yola: Weekly scope Adamawa printing Press.

Stout, B. (2007). Role of Agricultural Engineering in Economic development United Nations Asia and pacific center for AG Engineering and machinery.

\section{Copyrights}

Copyright for this article is retained by the author(s), with first publication rights granted to the journal.

This is an open-access article distributed under the terms and conditions of the Creative Commons Attribution license (http://creativecommons.org/licenses/by/3.0/). 